\title{
The Leading Role of East China Metropolitan Housing Markets: Panel Cointegration Tests
}

\author{
Gaolu Zou \\ Faculty of Tourism and Industrial Development, Chengdu University, Chengdu 610106, China
}

\begin{abstract}
House prices in four East China metropolises may lead those in other cities in China. The comovement between the metropolitan housing markets will reinforce their leading role in other housing markets. This paper aims to investigate the long-run relationship between four East China metropolises. The study used panel unit root and panel cointegration techniques. Tests suggested the long-run relationship existing between the East China housing markets of interest. This finding is at odds with existing studies. Average national-level city CPI positively influences housing markets. Therefore, a rational housing policy should center on East China metropolitan housing markets.
\end{abstract}

Keywords-east China coastal strip; metropolis; house price; housing market; panel unit root test; panel cointegration test.

\section{INTRODUCTION}

It has been often argued that the housing markets in Beijing, Shanghai, Guangzhou and Shenzhen are a first-tier housing market type. These markets have led the urban housing markets in any other regions of China. Similar fundamentals linking these metropolitan housing markets include coastal-strip location, large population size, developed economy and political status. In addition, developed transportation leads to very high accessibility between these cities. However, little literature supports this argument[1] suggest no cointegration for the Beijing, Shanghai and Guangzhou markets. Therefore, within a panel data setting, this paper aims to further test for a longrun relationship between the Beijing, Shanghai, Guangzhou and Shenzhen housing markets across East-China coastal strip.

\section{Methodology}

This study examined the long-run relationship using both the Fisher panel combined Johansen cointegration test and the Engle-Granger based panel cointegration test[2-5]. We estimates possible cointegrating coefficients using fully modified least squares (FMOLS)[2, 6, 7] and dynamic OLS (DOLS) [2, 3, 8-10]. Utilizing these estimated coefficients, we test for Granger causality from national city CPI to house price[11, 12]. Panel data can distinguish impacts that time series or cross section data alone cannot identify[7]. There has been an increasing literature to study housing markets using panel cointegration tests, e.g.[13-17].

\section{DATA}

Nomianl urban house price[18]was deflated by cityspecific consumer price index (CPI). Therefore, this study used the urban real house price (HP). We collected the cityspecific CPI series in metropolises' respective statistical information nets. HP_BEIJINGJ, HP_SHANGHAI, HP GUANGZHOU and $\overline{H P}$ SHENZHEN denote real house price in Beijing, Shanghai, Guangzhou, Shenzhen, respectively. House prices tend to move together with inflation rates in the long run[19-22]. Thus, we utilized national average city CPI as a given fundamental variable (CPI NATIONAL CITY)[18]. Additionally, the share of new housing transactions has been substantially high in China's city markets. Hence, we collected the nominal commodity housing prices of new housing properties. We utilized a panel data set. The panel data were monthly time series spanning the period from July-December 2010. Since 2011, China has implemented a house purchase control policy under which the housing market is highly restricted. Hence this study used the data before 2011. We seasonally adjusted the data using X13. We test for panel unit roots utilizing the Levin-Lin-Chu test[23] and the Breitung test[24].

\section{EMPIRICAL RESULTS}

The two tests suggested a unit root contained in the panel data (Table I). The Pedroni residual panel cointegration test suggested an existence of cointegration for the five series (Table II). Fisher combined panel cointegration test suggested at least two cointegrating vectors for the series. Thus, panel data set was cointegrated. Subsequently, we estimated the cointegrating coefficients using FMOLS and DOLS (Table III, Table IV). The elasticity of the house price in Beijing relative to the Shanghai, Guangzhou and Shenzhen prices was $0.15,0.47$, -0.02 . The elasticity of the house price in Beijing relative to the national city CPI was 0.13 . In addition, using the same specifications, we estimated the effects of CPI on the Shanghai, Guangzhou and Shenzhen prices, respectively (reported in Table III). 
TABLE I. THE PANEL UNIT ROOT TESTS

\begin{tabular}{llll}
\hline Method & $k$ & Level & First difference \\
\hline Levin, Lin and Chu & 5 & $0.02(0.51)$ & $19.26(0.00)$ \\
Breitung & 5 & $0.12(0.55)$ & $-9.76(0.00)$
\end{tabular}

Notes: data were in logarithms. $k$ is lag length. Tests selected $k$ using the Schwarz information criterion (SIC). Test equations contained both the trend and intercept. P-values are in parentheses.

TABLE II. THE PANEL COINTEGRATION TESTS

\begin{tabular}{|c|c|c|c|}
\hline Lag & Pedroni & Statistic & $\begin{array}{l}\text { P- } \\
\text { value }\end{array}$ \\
\hline \multirow[t]{6}{*}{10} & Panel v-Statistic & 6.02 & 0.00 \\
\hline & Panel rho-Statistic & -8.90 & 0.00 \\
\hline & Panel PP-Statistic & -10.12 & 0.00 \\
\hline & Panel ADF-Statistic & -8.80 & 0.00 \\
\hline & Fisher & & \\
\hline & $H_{0}$ & Fisher trace statistic & $\begin{array}{l}\mathrm{P}- \\
\text { value }\end{array}$ \\
\hline \multirow[t]{5}{*}{2} & 0 & 801.7 & 0.00 \\
\hline & $\leqslant 1$ & 463.8 & 0.00 \\
\hline & $\leqslant 2$ & 138.3 & 0.00 \\
\hline & $\leqslant 3$ & 84.4 & 0.15 \\
\hline & $\leqslant 4$ & 25.54 & 1.00 \\
\hline \multirow[t]{5}{*}{4} & 0 & 1076 & 0.00 \\
\hline & $\leqslant 1$ & 470.5 & 0.00 \\
\hline & $\leqslant 2$ & 115.2 & 0.00 \\
\hline & $\leqslant 3$ & 59.13 & 0.86 \\
\hline & $\leqslant 4$ & 91.41 & 0.06 \\
\hline \multirow[t]{5}{*}{6} & 0 & 1949 & 0.00 \\
\hline & $\leqslant 1$ & 1069 & 0.00 \\
\hline & $\leqslant 2$ & 633 & 0.00 \\
\hline & $\leqslant 3$ & 422.2 & 0.00 \\
\hline & $\leqslant 4$ & 174.2 & 0.00 \\
\hline
\end{tabular}

Notes: For the Pedroni test, test equations included both the trend and intercept. Tests selected a max lag of 10 using SIC. For the Fisher combined Johansen trace test, this study used Johansen's Model 4 and accordingly test equations included both the trend and intercept[25-27]. For comparison, tests used a lag of 2, 4 and 6, respectively.
TABLE III. ESTIMATED COINTEGRATION COEFFICIENTS USING FMOLS ESTIMATOR

\begin{tabular}{|c|c|c|c|c|}
\hline Variable & Coefficient & Std. error & t-statistic & P-value \\
\hline $\begin{array}{l}\text { Dependent: LOG } \\
\text { HP_BEIJING }\end{array}$ & & & & \\
\hline LOG HP_SHANGHAI & 0.15 & 0.03 & 5.25 & 0.00 \\
\hline $\begin{array}{l}\text { LOG } \\
\text { HP_GUANGZHOU }\end{array}$ & 0.47 & 0.03 & 13.55 & 0.00 \\
\hline LOG HP_SHENZHEN & -0.02 & 0.02 & -0.91 & 0.36 \\
\hline $\begin{array}{l}\text { LOG CPI_NATIONAL } \\
\text { CITY }\end{array}$ & 0.13 & 0.01 & 12.33 & 0.00 \\
\hline
\end{tabular}

Dependent: LOG HP

SHANGHAI

LOG CPI_NATIONAL

Dependent: LOG HP

GUANGZHOU

LOG CPI NATIONAL

$\begin{array}{lllll}\text { CITY } & -0.26 & 0.01 & -48.68 & 0.00\end{array}$

Dependent: LOG HP

SHENZHEN

LOG CPI_NATIONAL

CITY

0.13

0.01

12.33

0.00

\begin{tabular}{|c|c|c|}
\hline R-squared: & 0.64 & $\begin{array}{l}\text { Mean } \\
\text { dependent } \\
\text { var: }\end{array}$ \\
\hline Adjusted R-squared: & 0.63 & $\begin{array}{l}\text { S.D. } \\
\text { dependent } \\
\text { var: }\end{array}$ \\
\hline S.E. of regression: & 0.01 & $\begin{array}{l}\text { Sum squarec } \\
\text { resid: }\end{array}$ \\
\hline Durbin-Watson stat: & 0.72 & $\begin{array}{l}\text { Long-run } \\
\text { variance: }\end{array}$ \\
\hline
\end{tabular}

Notes: Test equations contained both the constant and linear trend[26]. Test used pooled estimation. Coefficient covariance was computed using homogenous variance. Long-run covariance estimation selected lag using SIC. 
TABLE IV.

ESTIMATED COINTEGRATION COEFFICIENTS USING DOLS ESTIMATOR

\begin{tabular}{|c|c|c|c|c|}
\hline Variable & Coefficient & $\begin{array}{l}\text { Standard } \\
\text { error }\end{array}$ & t-statistic & P-value \\
\hline \multicolumn{5}{|l|}{$\begin{array}{l}\text { Dependent: LOG } \\
\text { HP_BEIJING }\end{array}$} \\
\hline LOG HP_SHANGHAI & -0.10 & 0.02 & -4.77 & 0.00 \\
\hline LOG HP_GUANGZHOU & 0.34 & 0.03 & 12.04 & 0.00 \\
\hline LOG HP_SHENZHEN & 0.19 & 0.02 & 9.19 & 0.00 \\
\hline $\begin{array}{l}\text { LOG CPI_NATIONAL } \\
\text { CITY }\end{array}$ & 0.13 & 0.01 & 15.62 & 0.00 \\
\hline R-squared & 0.89 & $\begin{array}{l}\text { Mean } \\
\text { dependent } \\
\text { var } \\
\text { S. D }\end{array}$ & 1.02 & \\
\hline Adjusted R-squared & 0.86 & $\begin{array}{l}\text { dependent } \\
\text { var } \\
\text { Sum }\end{array}$ & 0.01 & \\
\hline S.E. of regression & 0.00 & $\begin{array}{l}\text { squared } \\
\text { resid }\end{array}$ & 0.02 & \\
\hline Long-run variance & 0.00 & & & \\
\hline
\end{tabular}

Notes: Test equation included the linear trend. Test used pooled estimation. Coefficient covariance was computed using homogenous variance. Leads and lags were selected using AIC.

TABLE V.TESTS FOR GRANGER CAUSALITY FROM CPI TO HOUSE PRICE

\begin{tabular}{|c|c|c|c|}
\hline Dependent & Explaining & Wald- $\chi^{2}$ & P-value \\
\hline LOG HP_BEIJING & $\begin{array}{l}\text { LOG } \\
\text { CPI_NATIONAL } \\
\text { CITY }\end{array}$ & 152 & 0.00 \\
\hline LOG HP_SHANGHAI & & 235 & 0.00 \\
\hline LOG HP_GUANGZHOU & & 2370 & 0.00 \\
\hline LOG HP_SHENZHEN & & 1000 & 0.00 \\
\hline
\end{tabular}

Notes: Granger causality tests were based on the panel cointegration estimates in Table 3.

\section{COMPUTATIONAL EXAMPLES AND ANALYSIS}

The long-run relationship exists between East China four metropolises. Evidence tends to reinforce the argument that these cities are the 'first-tier' city type in China. Some natural and socioeconomic fundamentals have linked these housing markets, which have facilitated their common trends. In addition, in the Beijing, Shanghai and Shenzhen markets, house prices change with CPI. Only in the Guangzhou market, CPI has a negative effect on the house price. Hence, generally speaking, CPI has a positive effect on house prices in east China housing markets. Granger causality tests in Table 5 suggested that CPI leads house prices.

\section{CONCLUSIONS}

This study examined the long-run relationship between east China four metropolises. These cities have been recognized as China's 'first-tier' city type, and thus their house prices have taken the lead of other cities. We tested for panel unit roots and panel cointegration. Tests suggested the existence of cointegration. Therefore, the long-run relationship exists between these east China housing markets. This finding contrasts with existing literature.
Additionally, the national average city CPI appears to have a positive effect on house price.

\section{REFERENCES}

[1] Zou, G.L. \& Chau K.W., Long-term equilibrium and short-term dynamics between metropolitan housing markets in china. Advanced Materials Research, 905, pp. 343-347, 2014.

[2] Pedroni, P., Purchasing power parity tests in cointegrated panels. Review of Economics and Statistics, 83(4), pp. 727-731, 2001.

[3] Kao, C., Chiang M.H. \& Chen B., International r\&d spillovers: An application of estimation and inference in panel cointegration. Oxford Bulletin of Economics and Statistics, 61(S1), pp. 691-709, 1999.

[4] Pedroni, P., Critical values for cointegration tests in heterogeneous panels with multiple regressors. Oxford Bulletin of Economics and Statistics, 61(S1), pp. 653-670, 1999.

[5] Banerjee, A., Panel data unit roots and cointegration: An overview. Oxford Bulletin of Economics and Statistics, 61(S1), pp. 607-629, 1999.

[6] Phillips, P.C. \& Hansen B.E., Statistical inference in instrumental variables regression with i (1) processes. The Review of Economic Studies, 57(1), pp. 99-125, 1990.

[7] Phillips, P.C. \& Moon H.R., Linear regression limit theory for nonstationary panel data. Econometrica, 67(5), pp. 1057-1111, 1999.

[8] Mark, N.C. \& Sul D., Cointegration vector estimation by panel dols and long - run money demand. Oxford Bulletin of Economics and Statistics, 65(5), pp. 655-680, 2003.

[9] Ho, T.-w., The government spending and private consumption: A panel cointegration analysis. International Review of Economics \& Finance, 10(1), pp. 95-108, 2001.

[10] Apergis, N. \& Payne J.E., Energy consumption and economic growth in central america: Evidence from a panel cointegration and error correction model. Energy Economics, 31(2), pp. 211-216, 2009.

[11] Granger, C.W.J., Investigating causal relations by econometric models and cross-spectral methods. Econometrica, 37(3), pp. 424438, 1969.

[12] Granger, C.W.J., Some properties of time series data and their use in econometric model specification. Journal of Econometrics, 16(1), pp. 121-130, 1981.

[13] Lumsdaine, R.L. \& Papell D.H., Multiple trend breaks and the unitroot hypothesis. Review of Economics and Statistics, 79(2), pp. 212218, 1997.

[14] Mikhed, V. \& Zemčík P., Do house prices reflect fundamentals? Aggregate and panel data evidence. Journal of Housing Economics, 18(2), pp. 140-149, 2009.

[15] Breitung, J. \& Pesaran M.H., Unit roots and cointegration in panels: Springer, 2008.

[16] Mikhed, V. \& Zemčík P., Testing for bubbles in housing markets: A panel data approach. The Journal of Real Estate Finance and Economics, 38(4), pp. 366-386, 2009.

[17] Beenstock, M. \& Felsenstein D., Spatial error correction and cointegration in nonstationary panel data: Regional house prices in israel. Journal of Geographical Systems, 12(2), pp. 189-206, 2010.

[18] NBSC. Statistical data: Monthly statistics. http://www.stats.gov.cn/. 2013.

[19] Spellman, L.J., Inflation and housing prices. Journal of the American Real Estate and Urban Economics Association, 9, pp. 205-222, 1981.

[20] Cho, D. \& Ma S., Dynamic relationship between housing values and interest rates in the korean housing market. Journal of Real Estate Finance \& Economics, 32(2), pp. 169-184, 2006.

[21] Adams, Z. \& Füss R., Macroeconomic determinants of international housing markets. Journal of Housing Economics, 19(1), pp. 38-50, 2010.

[22] Anari, A. \& Kolari J., House prices and inflation. Real Estate Economics, 30(1), pp. 67-84, 2002. 
[23] Levin, A., Lin C.-F. \& James Chu C.-S., Unit root tests in panel data: Asymptotic and finite-sample properties. Journal of Econometrics, 108(1), pp. 1-24, 2002.

[24] Breitung, J. \& Meyer W., Testing for unit roots in panel data: Are wages on different bargaining levels cointegrated? Applied Economics, 26(4), pp. 353-361, 1994.
[25] Johansen, S., Estimation and hypotheses testing of co-integration vectors in gaussian vector autoregressive models. Econometrica, 59(6), pp. 1551-1580, 1991.

[26] Hendry, D.F. \& Juselius K., Explaining cointegration analysis: Part ii. Energy Journal, 22(1), pp. 75-120, 2001.

[27] Johansen, S., Statistical analysis of cointegration vectors. Journal of Economic Dynamics and Control, 12(2-3), pp. 231-254, 1988. 